\title{
Acid neutralizing capacity minerals in Barani Pit PT Agincourt Resources Martabe, North Sumatera: alternative agent on neutralizing acid mine drainage
}

\author{
Rinal Khaidar Ali, Lestari Butar-butar, Nurakhmi Qadaryati*, Narulita Santi \\ Department of Geological Engineering, Faculty of Engineering, Diponegoro University, Semarang - \\ Indonesia
}

\begin{abstract}
Acid Mine Drainage (AMD) is produced when sulfide-bearing material is exposed to oxygen and water. The mine may accelerate this natural reaction due to the wide and rapid exposure of sulfide minerals. Although economical ores are considered environmental pollutants, there are several elements that act as acid neutralizing capacity (ANC) mineral are associated with the ore, especially silicate minerals. Currently, PT Agincourt Resources Martabe has only relying on the use of carbonates mineral groups to handle the AMD issue. In fact, the geological condition in this area is formed of typically alumina-rich and alkaline minerals which are capable to neutralize the AMD as well. The aim of this study is to determine ANC minerals from the rock formations that has impact to neutralize the AMD in Barani Pit. The methods are geological field observation, mineral determination using spectral analysis, and assay analysis that provides data to sort the recommended ANC minerals. The ANC minerals from the rock formations and wastes within Barani Pit, other than calcite, are muscovite, illite, smectite, kaolinite, dickite and gypsum. The knowledge about these alternative ANC minerals might give contribution to reduce and solve the risk of acid mine drainage polluting the environment.
\end{abstract}

Keywords. Acid mine drainage; acid neutralizing capacity; Barani Pit; silicate minerals.

\section{Introduction}

The mining of certain minerals, including gold, copper, and nickel, is associated with acid drainage problems that can cause long-term impairment to waterways and biodiversity. Acid Mine Drainage (AMD) is produced when sulfide-bearing material is exposed to

\footnotetext{
* Corresponding author : nurakhmi@live.undip.ac.id
} 
oxygen and water. The mine may accelerate this natural reaction due to the wide and rapid exposure of sulfide minerals [1].

Although these economical ores are considered environmental pollutants, there are several elements that act as acid neutralizing capacity mineral are associated with the ore [2]. This advantage can be applied to neutralize AMD that has already or inevitably occurred within the mine. The most effective known mineral to neutralize acid water is calcite [3], due to its alkalinity. Currently, PT Agincourt Resources Martabe, specifically Barani Pit as the studied area (Fig. 1.), has only relying on the use of carbonates mineral groups to handle the AMD issue. Meanwhile, silicate minerals such as quartz, kaolinite, illite, smectite, muscovite, actually also has the capability to neutralize AMD, despite the rate of reaction that is slower than the carbonate minerals [4].

The geological condition of the studied area is basically a product of hydrothermal process. The crystalized minerals, previously carried by the hydro thermal fluids, is rich in alumina and alkali, also volatile matters [5]. As mentioned previously, the alumina and alkaline minerals are capable to neutralize the AMD as well. Based on those facts, this study is conducted to run a preliminary test the impact of silicates provided in the rock formations to neutralize AMD within the mine. The aim of this study is to determine acid neutralizing capacity (ANC) minerals, especially from silicate mineral groups, within the rock formations that has impact to neutralize the AMD in Barani Pit.

\subsection{Regional Geology}

Martabe area (Fig. 1), in the regional geological map of Sibolga [6], is formed by seven lithology units, which are the Paleozoic metasediments of Tapanuli and Woyla Group, Barus Formation, Angkola Formation, Granitic Intrusion, coherent andesite Toru Formation, Martabe Dome Complex and Phreatic \& Phreatomagmatic Breccias. The distribution the lithology unit is shown in the regional geology map of Sibolga (Fig 2.). 


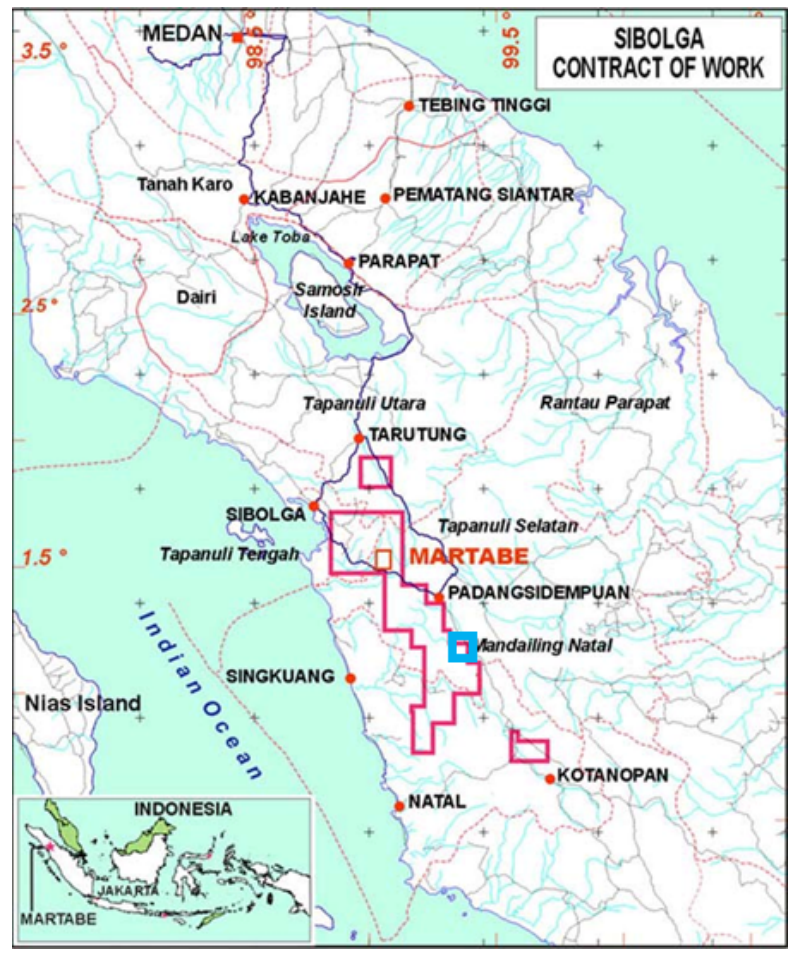

Fig. 1. Map of the surrounding studied area [6]. Location of Barani Pit shown in the blue lined square.

The Paleozoic metasediments is the basement of Martabe, consists of flysch, siltstonesclaystones, sandstones and conglomerates, with volcanics and epiclastics product as well. Late Oligocene-Middle Miocene Barus Formation is consist of conglomerates, sandstones (locally micaceous) and siltstones, also found sandy limestone and carbonaceous shale outcropped at the middle to south part of Martabe area. Angkola Volcanic Formation consist of four lithofacies, which are coherent basalt, coherent-trachytic basalt, coherentandesitic basalt and andesitic-basaltic volcanic breccia.

Uluhalanagodang Granite is a composite of granite to diorite batholith that dominate the eastern part of Martabe. This granite formed the sericite-chlorite-epidote alteration type as it intruded the Tapanuli Metasediment Group as seen in the vertical section (Fig. 3). Coherent andesite Toru Formation is composed of plagioclase-phyric-porphyri andesite. Martabe Dome Complex was formed due to periodic intrusions of Quartz-Phyric Dacite Porphyri and Hornblende-Phyric Andesite. The phreatic and phreatomagmatic breccia outcrop shows light gray and dark gray, muddy-matrix of carebonaceous mudstone and partly to fully silicified with disseminated pyrite [6]. Both of these facies are strongly altered shown by the occurrence of clay minerals with monomic and polymic fragments. 


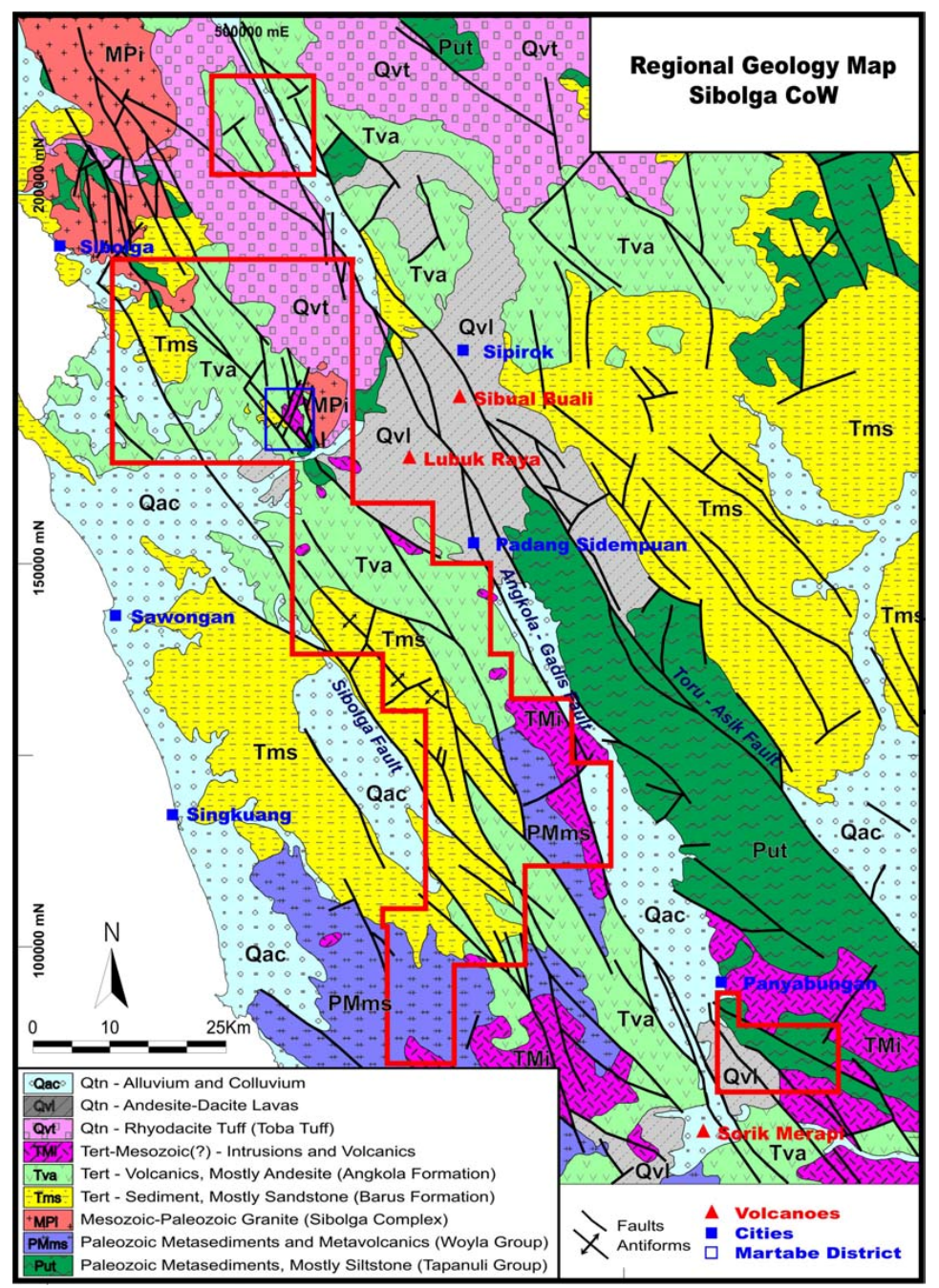

Fig. 2. Regional geological map of Sibolga area [6]. 


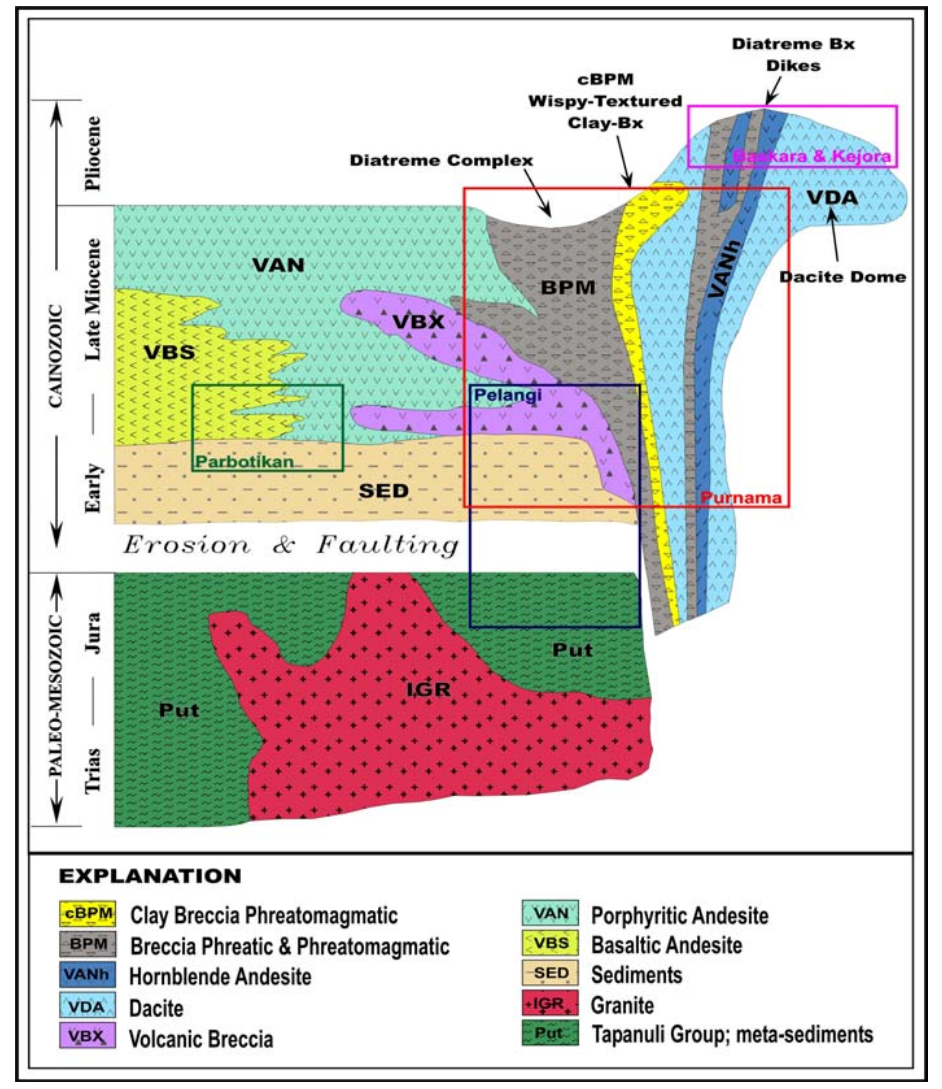

Fig. 3. Vertical section that ilustrate the reconstruction of subsurface geology [6].

\subsection{Acid mine drainage}

Mine materials that has the capability to form acids actually are from the overburden and even the coal or ore minerals itself, which consists of sulfide minerals [7]. When the minerals are exposed to the surface or have contact with groundwater, then the following reaction happened [8]:

$$
4 \mathrm{FeS}_{2}+15 \mathrm{O}_{2}+14 \mathrm{H}_{2} \mathrm{O} \rightarrow 4 \mathrm{Fe}(\mathrm{OH})_{3}+8 \mathrm{H}_{2} \mathrm{SO}_{4}
$$

The AMD management can be divided into preventive approach and curative approach (or remediation), based on the time of mining activity, before or during the mining and when the mining has nearly ended or post-mine, representatively. The preventive approach itself has several actions [7], which are: 1) overburden selective placement, 2) landscape design and revegetation, 3) addition of alkaline, 4) addition of phosphate, 5) bactericide injection and 6) encapsulation of acid forming minerals.

\subsection{Acid neutralizing capacity}

The unit that shows the nature ability of a mineral to neutralize acid is mentioned as acid neutralizing capacity (ANC), usually carbonate mineral has high ANC [9]. The Sobek method can estimate ANC of a mineral. The method is involving an addition of certain amount of chloride acid $(\mathrm{HCl})$ to the prepared rock samples which then continued by back 
titration (where the previous acid sample is being neutralized again) using $\mathrm{NaOH}$. The weight of $\mathrm{NaOH}$ in that back titration is equal to the ANC of mineral from the rock samples, where the unit is $\mathrm{kg} \mathrm{H}_{2} \mathrm{SO} 4 /$ ton [9].

\subsection{Statistical test of potential of acid mine drainage}

Basically, the statistic test, or else known as geochemical analysis, is conducted to identify the potential acid produced from overburden layers, which generally categorized as acid, neutral, or alkaline. The test is also called statistic because it does not consider the rate of acid forming.

The variables of the test include total sulfur, $\mathrm{pH}, \mathrm{pH}$ net acid generation, maximum potentially acidity, acid neutralizing capacity (ANC) and net acid producing potential. The test can determine the potential acid forming (PAF) and non-acid forming (NAF) of the rock formations [7]. Barani Pit has set the classification for their AMD shown in Table 1.

\section{Methodology}

\subsection{Geological field observation}

The data obtain from this method are the lithology description including structure, texture and constituent composition. The data are recorded from each observation point shown in Fig. 4. Outcrop samples are also collected during this observation, where the samples are later being prepared for mineral determination.

\subsection{Mineral determination}

The analysis was applied on 97 chosen samples of outcrops (locations in Fig. 4). The grabbed samples represented the altered lithology in Barani Pit and must be in dry condition when the analytical spectral device is measuring the sample. The concept of this analysis is by capturing the wavelength and reflectance of minerals, because the value of those parameters is specific on every mineral, that can lead to identify certain minerals.

\subsection{Assay analysis}

The analysis includes rinse $\mathrm{pH}$ that is done measuring the $\mathrm{pH}$ of rock by crushing the rock samples without considering the homogeneity of the samples. After that, the back titration is conducted to measure the acid neutralizing capacity of the samples. The percentage of calcium and sulfide sulfur is also measured in this analysis. This method is applied on 81 samples of rocks (locations in Fig. 4).

Table 1. Acid potential producing classification of Barani Pit [10]

\begin{tabular}{lllllll}
\hline Class & Descripton & $\begin{array}{l}\text { NAPP Lab } \\
\left(\mathrm{kg} \mathrm{H}_{2} \mathrm{SO} / \text { ton }\right)\end{array}$ & Logic & $\begin{array}{l}\mathrm{Rinse} \\
\mathrm{pH}\end{array}$ & Logic & $\begin{array}{l}\text { ANC Titration } \\
\left(\mathrm{kg} \mathrm{H} \mathrm{SO}_{2} / \text { ton }\right)\end{array}$ \\
\hline 1 & $\mathrm{NAF}$ & $<0$ & And & $>5,5$ & And & $\geq 0$ \\
\hline 2 & PAF - Low Risk & $0-5$ & And & $>4$ & And & $\geq 0$ \\
\hline 3 & PAF & $>5-90$ & And & $>3,5$ & And & $>-5$ \\
\hline 4 & PAF - High Risk & $>90$ & Or & $<3,5$ & Or & $<-5$ \\
\hline 5 & PAF- LAG & $>5-90$ & And & $>5,5$ & And & $>10$ \\
\hline
\end{tabular}




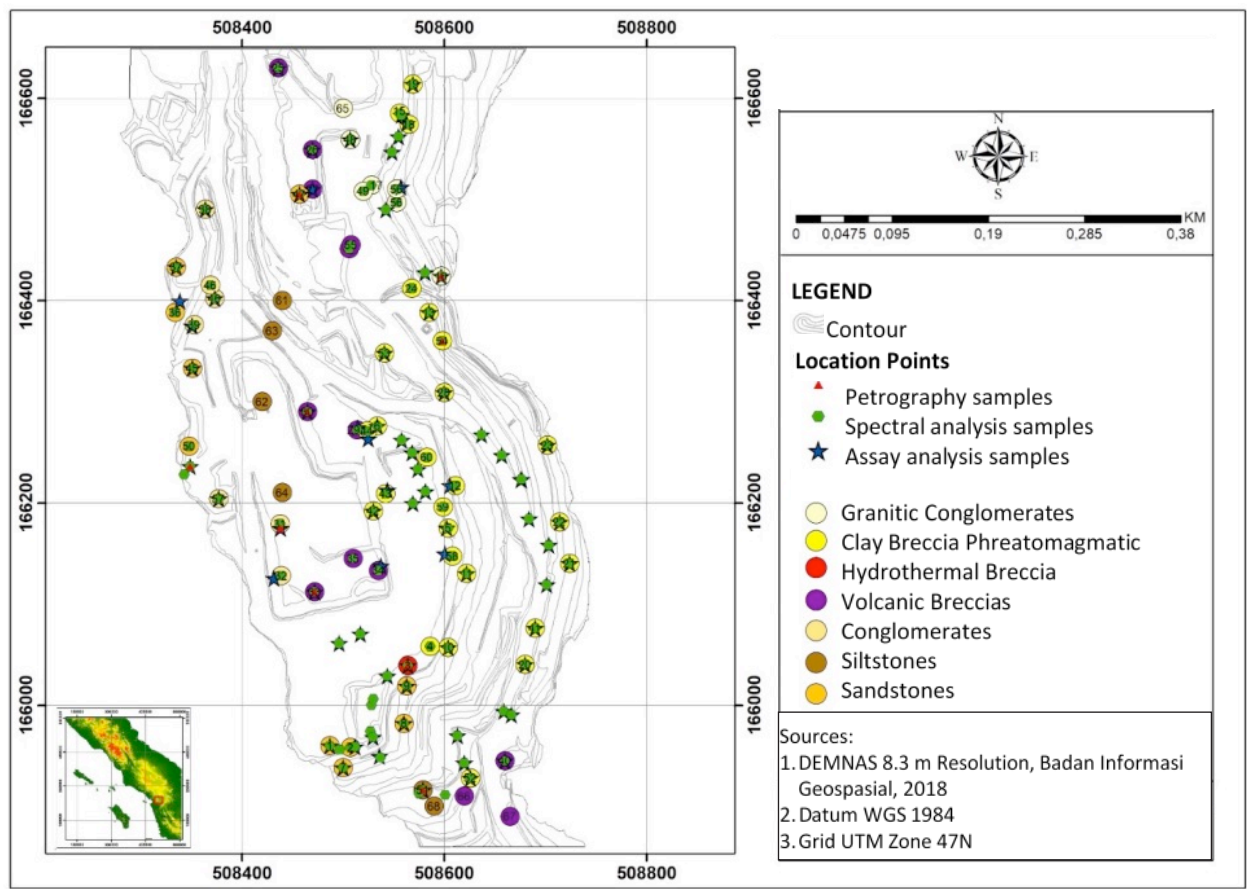

Fig. 4. Location point map of samples in Barani Pit

\subsection{Acid neutralizing capacity mineral sorting}

The procedure to sort the acid neutralizing capacity (ANC) starts by classifying waste based on Table 1. The qualified mineral is the non-acid forming (NAF), the low risk potentially acid forming (PAF-LR) and the low acid generation potential acid forming (PAF-LAG), while the others will not be included on the next sorting. On the other hand, the mineral on outcrop samples are also divided into compatible ANC minerals (calcite, muscovite, gypsum, illite, kaolinite, dickite and smectite) and non-compatible ANC minerals (hematite, geotite, chlorite, jarosite, quartz and alunite), where the later are minerals that are rejected. The qualified minerals were further being sorted by only selecting minerals that have ANC value $>30 \mathrm{H} 2 \mathrm{SO} 4 /$ ton, moreover, with the composition of calcium $<0.1 \%$ and sulfide sulfur $>0.8 \%$. The work flow of the sorting procedure is displayed Fig 5 .

High ANC in rock samples with low composition of calcium $(<0.1 \%)$ may indicate other element that act as the alkaline that were usually provided by the carbonate minerals. Whilst high ANC rock sample but have sulfide sulfur composition $>0.8 \%$ may also indicate alkaline minerals that suppress the acid forming.

\section{Result and discussion}

\subsection{Geological condition}

Based on the geological field observation and clay mineral determination, the study area is composed of eight lithology units. The defined lithology units were named referring to the existing geological name [6], which are:1. Sandstones Unit (SST); 2. Conglomerates Unit (SCG);. 3. Siltstones Unit (SSL); 4. Volcanic Breccia Unit (VBX); 5. Clay Breccia 
Phreatomagmatic Unit (CBPM); 6. Hydrothermal Breccia Unit (VBX); 7. Granitic Conglomerates; and 8. Blacksiltstones Unit.

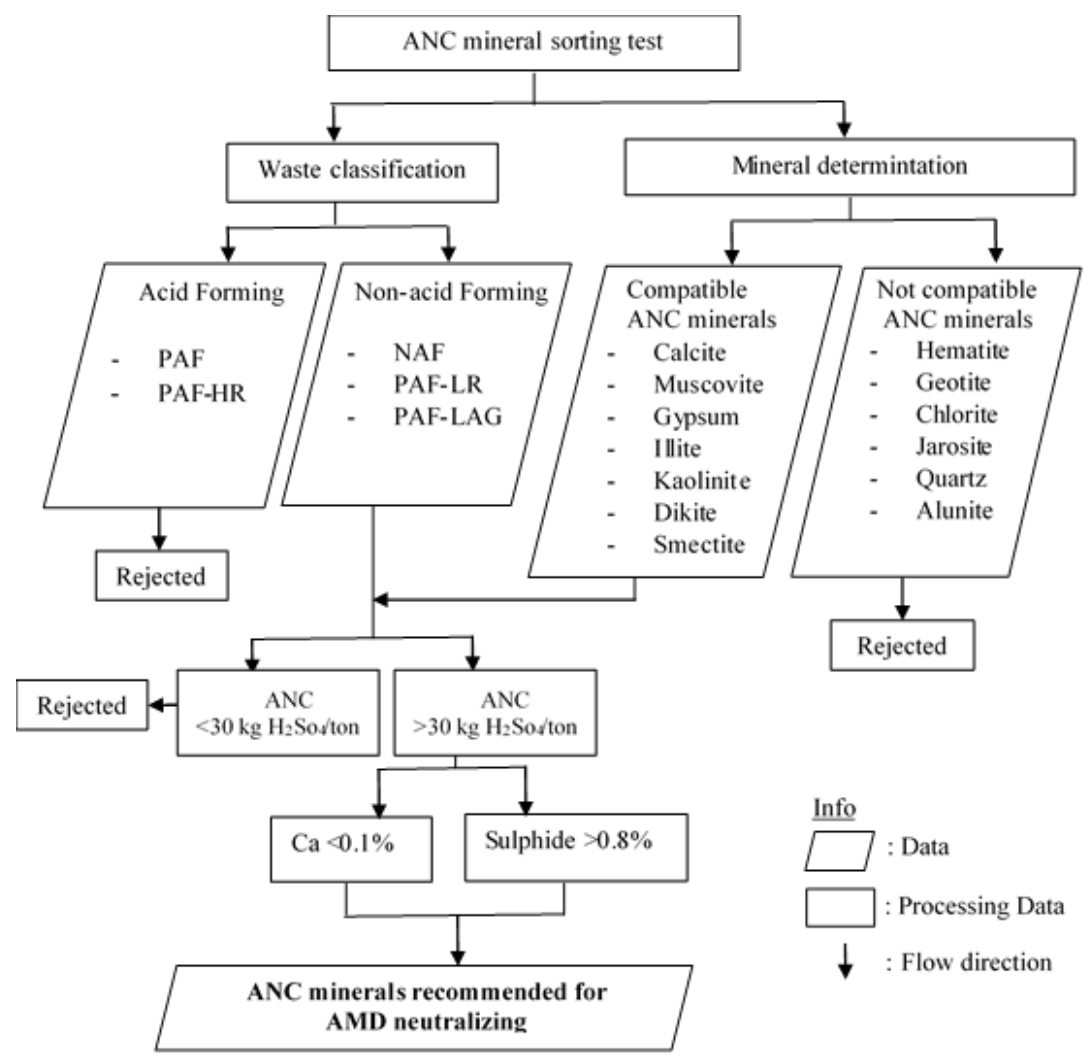

Fig. 5. The work flow of ANC mineral sorting. 


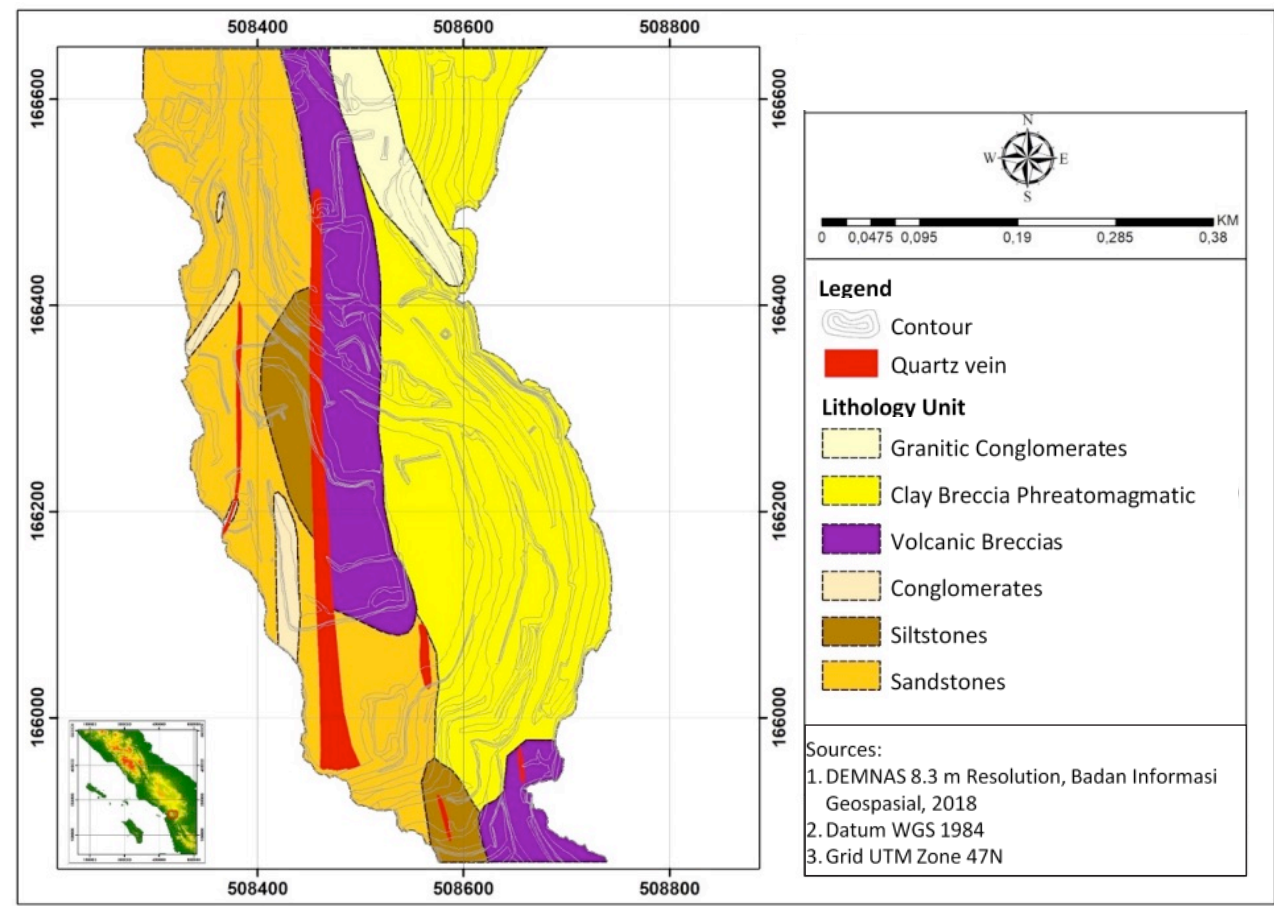

Fig. 6. Geological map of study area.

The distribution of the lithology units is displayed in the geological map in Fig. 6., where the area of VBX and Blacksiltstones are too narrow, hence, excluded in the map. Quartz vein is known to formed in a north-south trend, most possibly due to the fault orientation of the study area.

\subsection{Acid Neutralizing Capacity Minerals}

The analytical spectral device has identified several minerals that are composing the rock formations, which are quartz, silicate, muscovite, gypsum, hematite, jarosite. The device also shows clay minerals which are illite, smectite, kaolinite, calcite, muscovite, quartz, dickite, and chlorite. The occurrence of these clay minerals is most possibly not carried by the provenance of the clastic sedimentary rocks, instead, it was a product of alteration due to hydrothermal process. The ANC measurement result of the same outcrop samples on previous method that has $>30 \mathrm{H} 2 \mathrm{SO} 4 /$ ton is shown in Table 1, also displayed along with the percentage of calcium, sulfide sulfur and mineral composition.

Referring to Table 2. and coincide with the previous study [4], there are several ANC minerals that are qualified to neutralized the AMD, other than calcite or carbonate minerals. The silicate minerals in Barani Pit that is most likely to be recommended as AMD neutralizer are muscovite $\left(\mathrm{KAl}_{2}\left(\mathrm{AlSi}_{3} \mathrm{O}_{10}\right)(\mathrm{F}, \mathrm{OH})_{2}\right)$, where this mineral is basically composing all the rock samples that has $\mathrm{ANC}>30 \mathrm{H} 2 \mathrm{SO} 4 /$ ton. 
Table 2. Recapitulation data of spectral and assay analysis.

\begin{tabular}{|c|c|c|c|c|c|}
\hline \multirow{2}{*}{$\begin{array}{l}\text { Sample } \\
\text { location }\end{array}$} & \multirow{2}{*}{$\begin{array}{c}\mathrm{ANC} \\
\left(\mathrm{H}_{2} \mathrm{SO} / \mathrm{ton}\right)\end{array}$} & \multirow{2}{*}{$\begin{array}{l}\mathrm{Ca} \\
(\%) \\
\end{array}$} & \multirow{2}{*}{$\mathrm{S}_{2}(\%)$} & \multicolumn{2}{|c|}{ Spectral Analysis by ASD } \\
\hline & & & & Clay minerals & Other minerals \\
\hline STA 6 & 33,64 & 0.06 & 1.58 & Kaolinite + Illite & Muscovite+ Gypsum \\
\hline STA 9 & 39,82 & $<0.05$ & & Kaolinite+Dickite+Quartz & \\
\hline STA 23 & 55,1 & & & Illite+ Smectite & Muscovite+ Gypsum \\
\hline STA 25 & 77,75 & $<0.05$ & & Dickite + Kaolinite & Muscovite \\
\hline STA 28 & 56,99 & 0.08 & 1.29 & Illite & Muscovite+ Gypsum \\
\hline STA 33 & 66,37 & $<0.05$ & & Kaolinite & \\
\hline STA 41 & 38,02 & & & Illite + Smectite & Muscovite \\
\hline STA 44 & 174,5 & 0.025 & 1.27 & Illite + Kaolinite + Klorit & Muscovite \\
\hline STA 47 & 43,34 & $<0.05$ & & Kaolinite + Dickite & \\
\hline STA 80 & 39,58 & & & Illite+ Kaolinite & Muscovite+ Gypsum \\
\hline STA 81 & 81,57 & & 0.99 & Illite+ Kaolinite & Muscovite+ Gypsum \\
\hline STA 82 & 77,6 & & & Illite+ Kaolinite & Muscovite+ Gypsum \\
\hline STA 83 & 34,14 & & 1.18 & Illite+ Kaolinite & Muscovite+ Gypsum \\
\hline STA 84 & 82,76 & & 0.79 & Illite+ Kaolinite & Muscovite+ Gypsum \\
\hline STA 88 & 35,34 & & 1.79 & Illite+ Kaolinite & Muscovite \\
\hline STA 89 & 51,3 & & 1.11 & Illite+ Kaolinite & Muscovite \\
\hline STA 95 & 78 & & & Kaolinite + Illite & Muscovite \\
\hline STA 96 & 97,59 & & 1.07 & Illite+ Smectite & Kalsit+ Muscovite \\
\hline STA 97 & 81,94 & & & Illite+ Smectite & Kalsit+ Muscovite \\
\hline
\end{tabular}

There are four clay minerals in Barani Pit recommended as AMD neutralizer: illite, smectite, kaolinite and dickite. Illite $\left.\left(\mathrm{K}, \mathrm{H}_{3} \mathrm{O}\right)(\mathrm{Al}, \mathrm{Mg}, \mathrm{Fe})_{2}(\mathrm{Si}, \mathrm{Al})_{4} \mathrm{O}_{10}\left[(\mathrm{OH})_{2},\left(\mathrm{H}_{2} \mathrm{O}\right)\right]\right)$ has similar composition and mineralogy to muscovite, which might also a product of weathered muscovite. This mineral has potassium, that act as the alkaline, and aluminum, known as weak base. Smectite $(\mathrm{Na}, \mathrm{Ca})(\mathrm{Al}, \mathrm{Mg})_{6}\left(\mathrm{Si}_{4} \mathrm{O}_{10}\right)_{3}(\mathrm{OH})_{6}-\mathrm{nH}_{2} \mathrm{O}$ that is consist of $\mathrm{Na}, \mathrm{Ca}$, known as strong base. As kaolinite and dickite has the same chemical element $\left(\left(\mathrm{Al}_{2}\left(\mathrm{SiO}_{s}\right)(\mathrm{OH})_{4}\right)\right.$, they have potassium as the basic element.

Cation exchange is expected to happened when these minerals are added to acid water. The proton $\left(\mathrm{H}^{+}\right)$will intrude the $\mathrm{SiO}$ layers, and replacing the cations ( $\mathrm{Al}, \mathrm{K}$ and $\mathrm{Mg}$ ). Later, the $\mathrm{H}+$ is decreased in the dissolution. This condition means $\mathrm{pH}$ gaining in the dissolution, hence, in this case, reducing acidity of the acid water drainage.

Gypsum is also identified as ANC mineral in Barani Pit. The chemical composition of gypsum consists of $\mathrm{Ca}, \mathrm{H}, \mathrm{CaO}, \mathrm{H}_{2} \mathrm{O}$ and $\mathrm{S}$. Calcium oxide in gypsum, also known as pebble quick lime, is categorized as substrate that is favorable for AMD neutralizing [4].

\section{Conclusion}

The research has figured out the acid neutralizing minerals from the rock formations and wastes within Barani Pit, other than calcite as the most well-known ANC mineral. The minerals are muscovite, illite, smectite, kaolinite, dickite and gypsum. The knowledge 
about these alternative ANC minerals might send contribution to reduce and solve the risk of acid mine drainage polluting the environment.

\section{Acknowledgement}

The authors would like to thank PT. Agincourt Resources Martabe to give permission on collecting samples in Barani Pit and run analysis in the laboratorium.

\section{References}

1. A. Akcil, S. Koldas, J. Cleaner Prod. 14 (2006)

2. T. Chen, B. Yan, C. Lei, X. Xiao, Hydrometallurgy 147-148 (2014)

3. J. Skousen, J.K. Politan, T. Hilton, A. Meek, Green Lands 20, 4 (1990)

4. N. Said, JAI 7, 2(2014)

5. A.M. Bateman, M.L. Jensen, Economic Mineral Geothermal Systems (Geology Lecture Course, University of Auckland, 1981)

6. B. Sutopo, The Martabe Au-Ag High-Sulfidation Epithermal Deposits, Sumatra, Indonesia: Implications For Ore Genesis And Exploration (University of Tasmania Australia, 2013)

7. A. Munawar, Pengelolaan Air Asam Tambang: Prinsip-prinsip dan Penerapannya (UNIB PRESS Lembaga Penelitian Universitas Bengkulu, 2017)

8. S.R Jennings, D.R. Neuman, P.S. Blicker, Acid Mine Drainage and Effects on Fish Health and Ecology: A Review (Reclamation Research Group Publication, Bozeman, 2008)

9. A.A. Sobek, J.G. Skousen, S.E. Fisher, Chemical and physical properties of overburden and minesoils (West Virginia University and the National Mine Land Reclamation Center, West Virginia, 1996)

10. N. Khariyah, Martabe Mine Geology Manual Book (PT Agincourt Resources Martabe, North Sumatera, 2018) 